\title{
Research and prospect of peptides for use in obesity treatment (Review)
}

\author{
YAO GAO*, XUEWEN YUAN* ${ }^{*}$ ZIYANG ZHU, DANDAN WANG, QIANQI LIU and WEI GU \\ Department of Endocrinology, Children's Hospital of Nanjing Medical University, Nanjing, Jiangsu 210008, P.R. China
}

Received December 24, 2019; Accepted September 8, 2020

DOI: $10.3892 / \mathrm{etm} .2020 .9364$

\begin{abstract}
Obesity and its related diseases, such as type 2 diabetes, hypertension and cardiovascular disease, are steadily increasing worldwide. Over the past few decades, numerous studies have focused on the differentiation and function of brown and beige fat, providing evidence for their therapeutic potential in treating obesity. However, no specific novel drug has been developed to treat obesity in this way. Peptides are a class of chemically active substances, which are linked together by amino acids using peptide bonds. They have specific physiological activities, including browning of white fat. As signal molecules regulated by the neuroendocrine system, the role of polypeptides, such as neuropeptide Y, brain-gut peptide and glucagon-like peptide in obesity and its related complications has been revealed. Notably, with the rapid development of peptidomics, peptide drugs have been widely used in the prevention and treatment of metabolic diseases, due to their short half-life, small apparent distribution volume, low toxicity and low side effects. The present review summarizes the progress and the new trend of peptide research, which may provide novel targets for the prevention and treatment of obesity.
\end{abstract}

Correspondence to: Professor Wei Gu or Professor Qianqi Liu, Department of Endocrinology, Children's Hospital of Nanjing Medical University, 72 Guangzhou Road, Nanjing, Jiangsu 210008, P.R. China

E-mail: guwei154@163.com

E-mail: 18951769617@163.com

${ }^{*}$ Contributed equally

Abbreviations: AM2, adrenomedullin-2; BAT, brown adipose tissue; Ghrelin, growth hormone-releasing peptide; GLP-1, glucagonlike peptide-1; HFD; high-fat diet; MHC, major histocompatibility complex; NMUR, neuromedin U receptors; NPY, neuropeptide Y; PGC1 $\alpha$, peroxlsome proliferator-activated receptor- $\gamma$ coactlvator-1 $\alpha$; PPAR, peroxisome proliferators-activated receptor; PRDM16, positive regulatory domain containing 16; UCP-1, uncoupling protein-1; WAT; white adipose tissue.

Key words: obesity, peptidomics, peptides, treatment, metabolic diseases

\section{Contents}

1. Introduction

2. Definition and classification of adipose tissue

3. Definition and classification of polypeptides

4. Modes of action of polypeptides

5. Classical polypeptides in obesity

6. Study on new polypeptides in obesity

7. Conclusion

\section{Introduction}

Obesity is a nutritional disorder that is caused by the excessive accumulation of white adipose tissue (WAT) in the body, which is characterized by a high body mass index and interferes with the body's energy balance (1). Obesity is a major risk factor for a number of different diseases, such as type 2 diabetes, cardiovascular disease, hypertension, fatty liver disease and some malignant tumors $(2,3)$. The health of an individual is not only impeded by obesity, but it also causes huge economic losses to families and society (4).

The treatment of obesity primarily focuses on diet and physical exercise (5). When lifestyle changes fail, drugs and surgery will be considered as treatment options (6). At present, a number of so-called anti-obesity drugs have been developed, which affect digestion and absorption (7). These drugs can produce significant weight loss in the individual; however, some patients are unwilling to receive this type of treatment, due to side effects such as insomnia, hypertension and dizziness (5). Polypeptide drugs have been widely used in the prevention and treatment of various diseases, due to their notable pharmacodynamics, low dosage and low number of side effects (8). By 2015, 140 types of polypeptide drugs had entered clinical trials, and $>500$ types of polypeptide drugs were in the pre-clinical stage (9). The majority of polypeptides act as signaling molecules in the regulation of the neuroendocrine system to prevent obesity and type 2 diabetes (10). Peptides have become a novel research area for the potential treatment of metabolic diseases such as diabetes and hyperlipidemia. A number of reports have demonstrated the roles of peptides, such as neuropeptide Y (11), adrenomedullin 2 (12), atrial natriuretic peptide and brain natriuretic peptide (13), in the treatment of obesity. The present review describes the progress and trend of polypeptides in obesity research, a novel target for the prevention and treatment of obesity and its related complications. 


\section{Definition and classification of adipose tissue}

There are two types of adipose tissue in mammals: WAT, which stores energy in the form of lipids, and brown adipose tissue (BAT), which produces heat by consuming energy (14). WAT is widely distributed throughout the body and is responsible for obesity (15). On the basis of its location, WAT can be divided into visceral WAT and superficial WAT, also known as the inguinal WAT (15). The concept of BAT was first described in the 16th century, and it was originally thought to exist only in hibernating mammals and infants (16). However, in 2007, BAT was identified to be present in the supraclavicular and neck of the human body (16). In the subsequent 2 years, functional BAT was identified in adults (17-19). BAT can be activated by cold stimulation and produce a non-trembling fever (20). This process primarily relies on the mitochondrial brown fat uncoupling protein-1 (UCP-1) protein, which produces a proton gradient, that is then oxidized and phosphorylated through the respiratory chain in the mitochondrial inner membrane to produce heat (21). It is worth noting that individuals with low body fat have higher BAT activity compared with that in individuals with high body fat, indicating its role in reducing obesity (22). Recently, brown-like adipocytes, which are also known as beige adipocytes, have been described within the WAT, particularly in white inguinal adipocytes $(23,24)$. Beige adipocytes are similar to brown adipocytes morphologically, as they contain multilocular lipids and have a high number of mitochondria enriched by UCP-1 (25). Furthermore, beige adipocytes possess numerous BAT-specific genes, including UCP-1, cell death-inducing DNA fragmentation factor, Peroxisome proliferator-activated receptor gamma coactivator $1-\alpha$ (PGC-1 $\alpha$ ), positive regulatory domain containing 16 (PRDM16) and CCAAT/enhancer binding protein Beta; $\mathrm{GH}$, growth hormone (26). Beige cells show similar functions to brown adipocytes, such as producing heat $(25,27)$ and increasing the use of nutrients to assist with the balance of energy throughout the body (28). Typically, the process that promotes the transformation of white fat to beige fat is called browning of white fat, and could be used as a potential strategy to treat obesity (25). A number of genes have been indicated to be responsible for the browning of white fat, including PRDM16 and peroxisome proliferators-activated receptors (PPARs). Activation of PPAR $\alpha$ has been shown to promote the action of beige adipocytes via PRDM16 and PGC-1 $\alpha$ (29). PPAR $\gamma$ activator/agonist has been widely used to induce browning of white fat (30-32). The browning effect has been associated with the induction of PGC-1 $\alpha$ expression following PPAR agonist treatment $(30,33)$. In recent years, it has been demonstrated that polypeptides serve an important regulatory role in brown fat activation and differentiation, and the browning of white fat.

\section{Definition and classification of polypeptides}

A polypeptide is a type of small molecular compound, which is composed of amino acids and linked by peptide bonds (34). A polypeptide synthesized by two amino acids is called a dipeptide, and similarly, there are tripeptides and tetrapeptides. Generally, polypeptides consisting of 2-9 amino acids in length are termed oligo-peptides and those $>10$ amino acids in length are termed polypeptides (34). Typically, the term protein refers to polypeptides containing more amino acids (usually $>20$ ), such as leptin (34). Polypeptides serve an important role at the physiological or pathological level, and participate in the occurrence and development of a number of diseases (34). Polypeptides can be divided into endogenous or exogenous polypeptides, depending on the source. Endogenous polypeptides are important regulators of biological processes originating from endogenous proteolysis events or peptides encoded by non-coding RNA (35-37), and exist in the human body and have biological activities such as promoting energy metabolism and inhibiting insulin resistance. Exogenous polypeptides are bioactive peptides that exist in the natural world, such as in plants or animals (38). Peptides can act on specific target organs by either paracrine or autocrine signaling (38). Exogenous polypeptides can be divided into physiological active peptides and food sensory peptides, according to their function. Physiological active peptides serve an important role in the body, and include antimicrobial, neuropeptide and antihypertensive peptides, while food sensory peptides refer to those that have no physiological activity but have food sensory properties, such as enzymatic hydrolysates of soybean protein (food additives), methyl aspartate (sweeteners) and ornithine-B-alanine acids (bitter peptides) (38).

\section{Modes of action of polypeptides}

Polypeptides serve important roles in inflammation, tumor development, metabolic diseases, nervous system diseases and circulatory system diseases (39-42), and exert their functions through a variety of complex methods, primarily involving receptor binding, protein interaction and hormone activation (Table I).

Receptor binding. The receptor is an important molecule that provides physiological regulation within the human bod by binding with the ligand to transduce biological signals (9). Peptides can specifically recognize and bind to receptors on the cell surface, thus exerting the effects of agonists or inhibitors (9). For example, neuropeptide Y (NPY) is involved in the establishment of insulin resistance in adipose tissue via the long-term overexpression of NPY5 receptor in the paraventricular nucleus (43), while neuromedin $S$ can bind to neuromedin U receptors (NMUR; NMUR1 and NMUR2) (38). It is well-known that leptin inhibits food intake and increases energy consumption by acting on receptors in the central nervous system to regulate the activity of appetite-related central neurons in the brain (44).

Protein interactions. A protein is the final form of gene function. Some polypeptides can bind to proteins directly, which hinders the normal function of the protein (45). For example, the long non-coding (lnc)RNA HOXB-AS3 encodes a conserved 53 amino acid peptide (8). The HOXB-AS3 peptide, not lncRNA, suppresses colon cancer growth by binding to its protein competitively (8). A small number of polypeptides can also affect the conformation and folding of proteins by directly binding with target proteins. For example, Amyloid beta peptide of Alzheimer's disease directly binds to the target 
Table I. Mode of action of peptides.

\begin{tabular}{|c|c|c|c|c|}
\hline Mode of action & Typical peptides & Features & Function & (Refs.) \\
\hline \multirow[t]{2}{*}{ Receptor binding } & Neuropeptide Y & Acts via the Y5 Receptor & $\begin{array}{l}\text { Increased insulin resistance in } \\
\text { adipose tissue }\end{array}$ & (43) \\
\hline & Leptin & $\begin{array}{l}\text { Receptors of the central nervous } \\
\text { system }\end{array}$ & $\begin{array}{l}\text { Inhibiting food intake and } \\
\text { increasing energy consumption }\end{array}$ & (44) \\
\hline Protein interaction & $\mathrm{A} \hat{\mathrm{I}}^{2}$ peptides & $\begin{array}{l}\text { Acts on proteins and changes } \\
\text { their structure }\end{array}$ & $\begin{array}{l}\text { Involvement in the pathogenesis } \\
\text { of Alzheimer's disease }\end{array}$ & (46) \\
\hline \multirow[t]{2}{*}{ Hormonal effect } & Ghrelin & $\begin{array}{l}\text { Combines with growth hormone } \\
\text { secretagogue receptor }\end{array}$ & $\begin{array}{l}\text { Promoting the secretion of } \\
\text { growth hormone }\end{array}$ & $(47)$ \\
\hline & Intestinal peptides & Induces gastric leptin release & Weight loss & $(48,49)$ \\
\hline
\end{tabular}

Ghrelin, growth hormone-releasing peptide.

protein and affects its conformation, serving a pivotal role in the pathogenesis of Alzheimer's disease (46).

Hormone effects. Some peptides can promote or inhibit the release of specific hormones. The gastric growth hormone releasing polypeptide (ghrelin) is a polypeptide composed of 28 amino acids (47). When ghrelin is combined with growth hormone secretagogue receptor, it can promote the secretion of growth hormone (GH) (47). In addition, several intestinal peptides have been indicated to induce gastric leptin release, leading to weight loss $(48,49)$.

\section{Classical polypeptides in obesity}

Introduction. Peptides have the advantage of being stable, having a low molecular weight and high lipophilicity (9). In recent years, the area of peptidomics has rapidly developed, and the association between numerous polypeptides have been investigated with the occurrence and prevention of obesity and its related complications $(50,51)$. Therefore, identifying novel polypeptide drugs, which could prevent and cure obesity would improve the regulatory network of adipocyte function and offer new possibilities for the treatment of obesity. A list of some classical peptides together with their targets, sources and functions are presented in Table II.

Leptin. Leptin is a protein hormone that is secreted by adipose tissue (52). It has been widely hypothesized that after entering the blood circulation, it participates in the regulation of sugar, fat and energy metabolism (52). Early in 1997, Montague et al (53) demonstrated that leptin was a significant regulator of human energy balance via genetic evidence. Studies have revealed that leptin treatment can cause anorexia, physical activity increase, weight loss and lead to endocrine function and metabolic changes, which have a positive effect on the diet and nondigestive behaviors of patients with leptin deficiency $(54,55)$. Leptin is primarily produced by adipose tissue, but the stomach also produces a small amount (56). Therefore, it was hypothesized that leptin may serve an important role in diet control by cooperating with other satiety peptides $(49,57)$. Evidence indicates that gastric leptin can be released by a number of intestinal peptides such as ghrelin and cholecystokinin $(49,56)$. In addition, it is known that insulin is a hormone released into the blood shortly following the ingestion of food, and can also stimulate the secretion of gastric leptin (58). In a previous study, insulin and leptin were indicated to increase WAT browning and energy consumption and prevent diet-induced obesity in combination, by activating hypothalamic neurons (59).

Over a period of time, there has been an increase in the amount of research investigating the role of leptin in the pathogenesis of obesity (60). However, recently, numerous studies have recognized that leptin may also participate in the adaptation to energy deficiency $(61,62)$. Some studies have indicated that leptin participates in the regulation of neuroendocrine response to starvation, the change of hormone concentration and has an impact on the activity of the sympathetic nervous system and reproductive function $(63,64)$.

$N P Y$. NPY is a type of polypeptide molecule that widely exists in the central and peripheral nervous system, is a single-chain polypeptide and is composed of 36 amino acids (65). Injection of NPY into the hypothalamus has been revealed to induce appetite and regulate energy metabolism, and the expression level of NPY has previously been associated with leptin (66). Loh et al (67) demonstrated that knockout of NPY could alleviate obesity induced by leptin deficiency in mice. Previous studies have also revealed that NPY could not only antagonize the activity of the sympathetic nervous system, reduce the lipolysis of white adipocytes and inhibit the heat production of brown adipocytes (68), but could also directly act on NPY receptors in the peripheral adipose tissue to promote adipogenesis, leading to obesity (69). Furthermore, NPY is involved in the downstream mechanism of CREB phosphorylation by inhibiting cAMP accumulation and the cAMP-PKA-dependent p38 MAPK pathway (70). Wan et al (11) demonstrated that NPY reduces dibutyryl-cAMP activity of brown adipocytes by inhibiting brown fat-related gene expression and mitochondrial function.

Glucagon-like peptide-1 (GLP-1). GLP-1 is secreted by ileal endocrine cells and can promote insulin secretion (71). It has been successfully marketed as a drug to treat type 2 diabetes (71). In the treatment of obesity, it was previously found 
Table II. Common peptides in obesity research.

\begin{tabular}{|c|c|c|c|c|}
\hline Target & Peptide & Function & Source & (Refs.) \\
\hline Hypothalamic neurons & Leptin & $\begin{array}{l}\text { WAT browning (up) } \\
\text { Thermogenesis (up) }\end{array}$ & $\begin{array}{l}\text { Adipose tissue and } \\
\text { stomach }\end{array}$ & (59) \\
\hline CAMP-PKA-dependent pathways & Neuropeptide $\mathrm{Y}$ & $\begin{array}{l}\text { Adipogenesis (up) } \\
\text { Thermogenesis (down) }\end{array}$ & $\begin{array}{l}\text { Central and peripheral } \\
\text { nervous system }\end{array}$ & (70) \\
\hline Sirt- 1 dependent pathway & $\begin{array}{l}\text { Glucagon-like } \\
\text { peptide-1 }\end{array}$ & $\begin{array}{l}\text { Adipogenesis(down) } \\
\text { WAT browning (up) }\end{array}$ & Ileum & (77) \\
\hline Central appetite regulatory network & Ghrelin & $\begin{array}{l}\text { Adipogenesis (up) } \\
\text { Thermogenesis (down) }\end{array}$ & $\begin{array}{l}\text { Gastric, small intestine } \\
\text { and hypothalamus }\end{array}$ & $(81)$ \\
\hline Class II MHC and UCP1 & Adrenomedullin 2 & $\begin{array}{l}\text { Thermogenesis (up) } \\
\text { Insulin sensitivity (up) }\end{array}$ & Adrenaline & $(90)$ \\
\hline FGF21 and UCP1 & Irisin & $\begin{array}{l}\text { Thermogenesis (up) } \\
\text { Insulin sensitivity (up) }\end{array}$ & Muscle and adipose tissue & (93) \\
\hline PKA-mediated phosphorylation & Adropin & $\begin{array}{l}\text { Adipogenesis (down) } \\
\text { Insulin resistance (down) }\end{array}$ & Liver and brain & $(51)$ \\
\hline Unknown mechanism & Preptin & $\begin{array}{l}\text { Adipogenesis (up) } \\
\text { Insulin resistance (up) }\end{array}$ & Pancreas & $(100)$ \\
\hline
\end{tabular}

Sirt-1, Sirtuin; Ghrelin, growth hormone-releasing peptide; MHC, major histocompatibility complex; UCP1, uncoupling protein 1; up, increase; down, decrease.

that GLP-1 and its receptor agonists could inhibit food intake, reduce weight and alleviate obesity (72). The GLP-1 receptor is widely expressed in the hypothalamus, particularly in the supraoptic nucleus, the paraventricular nucleus and the arcuate nucleus (72). GLP-1 acts on the GLP-1 receptor to inhibit food intake (73). In a previous study, it was demonstrated GLP-1 receptor-KO mice did not become obese (74). Injecting GLP-1 into the peripheral or central nervous system has also been indicated to effectively reduce the intake of food in rats (74). Furthermore, Perez-Tilve et al (75) indicated that GLP-1 increased energy consumption and increased body temperature in patients with obesity. In an in vitro experiment, GLP-1 stimulation on differentiated 3T3 cells and human adipocytes was demonstrated to inhibit gene expression associated with differentiation and promote gene expression associated with lipid degradation (76). In addition, GLP-1 receptor has also been revealed to promote browning of white fat through the SIRT-1-dependent pathway (77).

Ghrelin. Ghrelin is a 28 -amino-acid polypeptide that is secreted by X/A-like cells of the gastric acid secreting glands, and is also expressed in the small intestine and the hypothalamus (78). Ghrelin is an endogenous ligand of the GH secreting hormone receptor (GHS-R), and when bound to GHS-R, it can stimulate the secretion of GH (78). In a previous clinical study, it was indicated that ghrelin injection caused a hunger response and significantly increased food intake (79). This is consistent with the fact that ghrelin injection could also promote gastrointestinal motility, stimulate gastric acid secretion and protect gastric mucosa (80). Ghrelin primarily acts through the central appetite regulatory network, and it is also the first confirmed active appetite promoting factor (81). Tschöp et al (82) revealed that injection of ghrelin into the ventricle or periphery of the rat brain increased food intake, which was also consistent with the effect of NPY injection. In additional studies, injection of ghrelin into the central nervous system of NPY-KO rats was demonstrated to increase food intake, suggesting that the role of ghrelin in promoting food intake does not depend solely on NPY (83). Furthermore, in animal studies $(84,85)$, it was also revealed that ghrelin could reduce energy metabolism, promote lipid accumulation in white adipocytes, inhibit BAT function and lead to obesity. Intervention of mature 3T3-L1 cells in vitro promotes the secretion of pro-inflammatory factors (86). In addition to the effect of dietary regulation on obesity, ghrelin also accelerates metabolism. The peripheral injection of ghrelin can reduce fat utilization in rodents and cause obesity, while the intracerebral injection can lead to food intake and weight gain (82). Notably, ghrelin has also been associated with sleep. Ghrelin increases within $1 \mathrm{~h}$ of sleep and regulates sleep-promoting GHs, which contribute to slow-wave sleep (87). Based on the multiple functions of ghrelin, ghrelin analogues, as stimulants and inhibitors, could be used as clinical drugs for the treatment of related diseases such as digestive and metabolic diseases, particularly in the treatment of obesity using ghrelin inhibitors (88).

Adrenomedullin-2 (AM2). AM2/intermediate is a secreted peptide, which serves a significant role in protecting the cardiovascular system $(50,89)$. AM2 treatment has been demonstrated to significantly reduce blood glucose levels, improve glucose tolerance and insulin sensitivity by inhibiting major histocompatibility complex (MHC) II in adipocytes (90). Similarly, in a mouse model, the aAM2 transgenic mice showed more energy consumption due to their increased oxygen consumption and carbon dioxide production (12). These effects may be due to the decrease of PGCl $\alpha$ acetylation and the increase of AMP activated protein kinase phosphorylation, which lead to the 
interaction between PGC1 $\alpha$ and PR domain containing 16, and the promotion of the uncoupling protein 1 (UCP1) expression in adipocytes $(12,91)$. These results suggest that upregulation of UCP1 is a way for endogenous AM2 to participate in energy metabolism of adipocytes.

Irisin. The irisin protein is encoded by the FNDC5 gene and is expressed in both human adipose tissue and muscle (92). A previous study demonstrated that irisin was associated with insulin resistance and obesity (93). The results indicated that the levels of circulating irisin and the expression level of the FNDC5 gene in adipose tissue and muscle were significantly lower in patients with obesity and type 2 diabetes compared with that in patients without these diseases, suggesting that the loss of brown-like characteristics may be a potential target for obesity treatment (93). Similarly, in a study by Pérez-Sotelo et al (94), using stable gene silencing of FNDC5, the results revealed that FNDC5-KO adipocytes exhibited reduced UCP1 expression levels and enhanced adipogenesis. In addition, a previous study revealed that FNDC5 and/or FGF21 treatment increased thermogenesis and upregulated brown fat gene expression, suggesting that exercise-induced irisin secretion may have evolved from muscle contraction associated with tremor, which in combination with FGF21, promotes brown fat thermogenesis (95). Irisin-mediated muscle-adipose crosstalk may represent a thermogenic, cold-activated endocrine axis, which could be used in the development of obesity therapeutics (95).

Adropin. Adropin is a secreted peptide that is composed of 76 amino acids translated from the energy homeostasis associated gene, which has been associated with metabolic control and vascular function (96). Adropin does not directly regulate food intake; however, it has been indicated to be involved in the prevention of insulin resistance, dyslipidemia and impaired glucose tolerance, thus preventing obesity (97). In in vitro experiments using primary mouse hepatocytes, adropin 34-76 was demonstrated to directly affect liver metabolism, and reduce glucose production and PKA-mediated phosphorylation (51). Gao et al (51) indicated that the major hepatic signaling pathways contributed to the improved glycemic control achieved with adropin 34-76 treatment in cases of obesity. In addition, the function of adropin gene $\mathrm{KO}$ was investigated in $\mathrm{C} 57 \mathrm{BL} / 6 \mathrm{~J}$ mice and the results revealed that adropin deficiency could aggravate the metabolic defects caused by a high-fat diet (HFD) (98). In cell experiments, adropin was found to reduce lipid accumulation, as well as the expression of proadipogenic genes in 3T3-L1 cells and rat preadipocytes, suggesting that adropin attenuates the differentiation of preadipocytes into mature fat cells (99). In summary, these results suggested that adropin serves an important role in fatty acid metabolism control, metabolic homeostasis, impaired glucose tolerance and protection from insulin resistance.

Preptin. Preptin is a derivative of the proinsulin growth factor II and composed of 34 amino acids (100). It is secreted by pancreatic islet $\beta$ cells and considered to be a physiological enhancer of insulin secretion (100). In addition, preptin can stimulate the proliferation, differentiation and survival of osteoblasts (101). In terms of metabolism, a previous study demonstrated that the primary function of preptin was to moderate glucose-mediated insulin release, which in return regulated the metabolism of carbohydrates, proteins and lipids (100). Consistent with this conclusion, another study revealed that preptin was significantly higher in patients who were obese and overweight compared with that in the control group, suggesting that the elevated serum preptin, together with insulin resistance are associated with obesity and overweight (102). In addition, a positive correlation was identified between the concentration of preptin and insulin resistance (102). However, the specific mechanisms governing this requires further investigation.

\section{Study on new polypeptides in obesity}

Functional peptides and their homologous fragments. The core functional fragments of polypeptides are very short, usually only a few amino acids in length, and highly homologous fragments often have similar functions (103). GLP-1 has two bioactive forms in vivo; GLP-1 (7-37) and GLP-1 (7-36) amides. Among them, GLP-1 (7-36) amides are easily degraded by dipeptidyl peptidase IV (DPP IV) and neutral endopeptidase (NEP) 24.11 in the blood (104). GLP-1 (7-36) was indicated to be cleaved by DPP IV to produce GLP-1 (9-36), while GLP-1 (28-36) and GLP-1 (32-36) were produced by NEP 24.11 (104). The role of GLP-1 (9-36) and GLP-1 (28-36) in promoting energy metabolism and inhibiting insulin resistance to prevent diabetes has been supported $(105,106)$. Recent studies have indicated that 5-peptide GLP-1 (32-36) also serves a similar role (107). Short peptides are more likely to escape the degradation of proteases and may have improved functions compared with that in the original versions, which is also an important way to modify polypeptide drugs (103). GLP-1 and its homologous fragments serve similar roles. Esenatide, a novel compound with natural GLP-1 activity, has been approved for use in the treatment of type 2 diabetes (108). These results suggested that novel polypeptide drugs to treat obesity using homology could be identified.

Fragmentation of protein molecules. Fragments of protein molecules were originally hypothesized to be non-functional peptide segments; however, recent studies have revealed that they have important functions $(109,110)$. These can be secreted as hormone molecules into the extracellular space, transported to target organs and serve similar or opposite roles with protein precursors (109). Early studies on slit guidance ligand 2 (SLIT2) have focused on brain development. A previous study (111) has revealed that beige adipocytes could synthesize and secrete SLIT2, which is regulated by the PRDM16 gene. In vivo experiments and cell studies have also revealed that SLIT2 could promote adipose tissue heat production, enhance energy metabolism and regulate blood sugar levels $(111,112)$. Further studies have indicated that the SLIT2 protein could be cleaved into fragments of different sizes, and the $50 \mathrm{kD}$ fragment of the C-terminal end also has a similar function of the SLIT2 protein (111). The mechanism of action is primarily through the activation of the PKA signaling pathway. Furthermore, previous studies investigating neonatal progeroid syndrome (NPS) have demonstrated that NPS was associated with the truncated mutation in the FBN1 gene at the 
$3^{\prime}$ end, which results in the inability of profibrillin to process fibrillin-1 and asprosin (the $25 \mathrm{kD}$ peptide segment) (113). Asprosin has been indicated to be significantly elevated in the blood in individuals who are insulin-resistant and in mouse models, to bind to liver surface receptors and promote the rapid increase of blood sugar levels by activating the ' $G$ protein-cAMP-PKA' signaling pathway (113).

Endogenous peptides in bodily fluid. Endogenous peptides are important regulators of a number of biological processes, including heredity, maturity, aging and death $(35,36)$. Among them, breast milk contains a number of natural peptides with different biological activities (114). It can regulate the immune system, and exhibits antimicrobial, antioxidant properties and decrease the risk of obesity, atherogenesis, arterial hypertension and type 2 diabetes $(114,115)$. A previous study demonstrated that Valine-Proline-Proline is a tripeptide derived from casein, is composed of three amino acids, which can improve insulin resistance in mice fed with a HFD, and alleviates inflammation by reducing the secretion of tumor necrosis factor- $\alpha$ and interleukin-1 $\beta$ (116). K-casein-derived glycogenous peptide has been indicated to inhibit the proliferation of adipocytes and reduce their lipid accumulation (117). By analyzing the differentially expressed polypeptides in the breast milk of macrosomia mothers, Cui et al (118) indicated that the polypeptide, casein 24 from $\beta$-casein in breast milk, exhibited a killing effect on common pathogenic bacteria in newborns, while k-casein 89 could inhibit the proliferation of human preadipocytes. These findings provide novel information that may be used in the prevention of obesity and reveal the important role of milk-derived peptides in this disease. Human bodily fluid contains a large number of endogenous polypeptides, most of which are also derived from degraded fragments of protein precursors (119). The study investigating milk-derived peptides further suggests that endogenous polypeptides in bodily fluids serve an important role in regulating obesity and other diseases and provides a novel method for the treatment of obesity and other diseases including atherogenesis, arterial hypertension and type 2 diabetes.

Function of intracellular peptides. Intracellular peptides are small molecular peptides that are 2-21 amino acids in length and are produced by proteasome or proteasome hydrolysis (120). Traditionally, the majority of these peptides are degraded by cell aminopeptidases, and a few are transferred to the endoplasmic reticulum to participate in antigen presentation of MHC I $(120,121)$. At present, $>400$ intracellular peptides (122-124) have been identified in mouse tissues and human cell lines, and typically serve a role in the regulation of signal transduction, mitochondrial stress, growth and development $(125,126)$. Since adipocytes are the primary site of lipid deposition, and obesity and its related complications are associated with the increase of adipocyte volume and dysfunction (1), research has now focused on the role of endogenous endopeptides in adipose tissue. In 2012, Berti et al (127) revealed that intracellular peptides (diazepam binding inhibitor, LDBI and VGN) derived from adipose tissue in rats could be used to improve insulin-induced glucose intake and it was preliminarily demonstrated that endopeptides were involved in adipocyte insulin resistance. EPO-derived Helix B-surface peptide, which is a source of erythropoietin, was demonstrated to inhibit the differentiation of 3T3L1 cells and secretion of inflammatory factors, as well as improving obesity and insulin resistance induced by a HFD (128). Na/K-ATPase-derived breakdown-derived peptide was also indicated to inhibit adipocyte differentiation and oxidative stress, thus reducing obesity and insulin resistance induced by a HFD (129). As a novel component of adipocyte function regulation, intracellular peptides are expected to receive more attention in future studies.

\section{Conclusion}

In the United States, the rate of obesity in both adults and adolescents has increased between 1999-2000 and 2013-2014, indicating that the existing treatment options have failed to effectively control the prevalence of obesity (130). By 2014, the obesity rate for adults and adolescents had reached 36 and $17 \%$, respectively in the USA (130). Peptide drugs have an effective molecular basis, such as a low molecular weight, good lipophilicity, easy nucleation and stability (9). An increasing amount of evidence in human and mice has revealed the potential of peptides, as a target of anti-obesity therapeutics (9). The development of peptide drugs has received more attention recently.

Peptidomics is a new branch of proteomics, which is based on the research of endogenous protein fragments. These endogenous protein fragments are different from the secreted pathway peptides that serve a role in the extracellular space, and are termed intracellular peptides, as they primarily exist in the cytoplasm, mitochondria and/or the nucleus (131). Intracellular peptides serve an important role in the energy metabolism of brown and white fat, and they have a high degree of homology in human and mouse cell lines (132). Notably, in clinical and preclinical practice, peptide drugs have made marked achievements in the treatment of energy metabolism, such as GLP-1 (133), adropin, preptin (100) and irisin (93). Furthermore, metformin, as a classic drug for the treatment of type 2 diabetes, also has a unique effect in reducing weight (134). In a previous study (135), potential active peptides were screened using metformin, providing potential targets for the treatment of obesity.

At present, the rapid development of proteomics has brought novel concepts to peptide research $(8,9)$. Among them, functional peptide homologous regions, fragments of protein molecules, and endogenous peptides produced by adipocytes, have attracted the attention of researchers $(103,109,114)$. On the other hand, new research has revealed that the short open reading frame of non-coding genes could also encode peptides $(35,136)$. These polypeptides could prevent insulin resistance and obesity caused by age and a HFD. The polypeptide derived from the non-coding gene, ribosomal RNAs and the candidate mRNA from the coding region, provides novel targets for identifying new peptides.

The advantages of peptide drugs are clear; however, there are also some side effects. The USA, European Union, Australia and Japan have approved several weight-loss drugs (9). These are co-agonists of a variety of gut hormones, including GLP-1, glucagon and gastric inhibitory peptide; however, they are rarely used in patients, partly due to concerns about safety and effectiveness, and due to inadequate coverage of health insurance (137). It is known that GLP-1R agonists 
could effectively treat obesity by inhibiting feeding and hyperglycemia through vagal afferent (138). However, given therapeutically, GLP-1 analogues have been demonstrated to cause side effects including nausea, vomiting and loss of appetite, which limits the dosage (139). Obesity is compounded by neurobiology (140). Therefore, reducing the side effects of peptide drugs and increasing the medical insurance system of obesity drug treatment is important (141).

In conclusion, with the rapid development of peptidomics, polypeptide research has become a new hotspot in the treatment of obesity. Furthermore, numerous polypeptide drugs have been developed for the treatment of obesity. The present review discussed the studies of polypeptides in obesity regulation, highlighted the new trend of polypeptides in obesity research, and introduced new concepts, such as endogenous polypeptide, further providing information on the potential molecular therapeutic targets that may be used in the treatment of obesity.

\section{Acknowledgements}

Not applicable.

\section{Funding}

The current study was sponsored by the grants from the National Natural Science Foundation of Jiangsu Province of China (grant no. BK20191123), Science and Technology Development Foundation Item of Nanjing Medical University (grant no. NMUB2019187).

\section{Availability of data and materials}

Not applicable.

\section{Authors' contributions}

YG collected and analyzed the current published data. YG and $\mathrm{XY}$ wrote and revised the manuscript. ZZ and DW contributed to the revision of the language and revised the work critically. WG and QL designed and revised the manuscript. All authors have read and approved the final manuscript.

\section{Ethical approval and consent to participate}

Not applicable.

\section{Patient consent for publication}

Not applicable.

\section{Competing interests}

The authors declare that they have no competing interests.

\section{References}

1. Spiegelman BM and Flier JS: Obesity and the regulation of energy balance. Cell 104: 531-543, 2001.

2. Haslam DW and James WP: Obesity. Lancet 366: 1197-1209, 2005.
3. Executive summary of the clinical guidelines on the identification, evaluation, and treatment of overweight and obesity in adults. Arch Intern Med 158: 1855-1867, 1998.

4. Bray GA, Heisel WE, Afshin A, Jensen MD, Dietz WH, Long M, Kushner RF, Daniels SR, Wadden TA, Tsai AG, et al: The science of obesity management: An endocrine society scientific statement. Endocr Rev 9: 79-132, 2018.

5. Jin J: JAMA patient page. Specific medications for weight loss. JAMA 314: 742, 2015.

6. Hill JO and Wyatt HR: Relapse in obesity treatment: Biology or behavior? Am J Clin Nutr 69: 1064-1065, 1999.

7. Wang $\mathrm{H}$ and Zhai F: Programme and policy options for preventing obesity in China. Obes Rev 14 (Suppl 2): S134-S140, 2013.

8. Ahrens VM, Bellmann-Sickert K and Beck-Sickinger AG: Peptides and peptide conjugates: Therapeutics on the upward path. Future Med Chem 4: 1567-1586, 2012.

9. Fosgerau K and Hoffmann T: Peptide therapeutics: Current status and future directions. Drug Discov Today 20: 122-128, 2015.

10. Greenwood HC, Bloom SR and Murphy KG: Peptides and their potential role in the treatment of diabetes and obesity. Rev Diabet Stud 8: 355-368, 2011.

11. Wan Y, Xue R, Wang Y, Zhang Q, Huang S, Wu W, Ye H, Zhang Z and Li Y: The effect of neuropeptide Y on brown-like adipocyte's differentiation and activation. Peptides 63: 126-133, 2015.

12. Zhang H, Zhang SY, Jiang C, Li Y, Xu G, Xu MJ and Wang X: Intermedin/adrenomedullin 2 polypeptide promotes adipose tissue browning and reduces high-fat diet-induced obesity and insulin resistance in mice. Int J Obes (Lond) 40: 852-860, 2016.

13. Bordicchia M, Liu D, Amri EZ, Ailhaud G, Dessì-Fulgheri P, Zhang C, Takahashi N, Sarzani R and Collins S: Cardiac natriuretic peptides act via p38 MAPK to induce the brown fat thermogenic program in mouse and human adipocytes. J Clin Invest 122: 1022-1036, 2012.

14. Lowell BB and Flier JS: Brown adipose tissue, beta 3-adrenergic receptors, and obesity. Annu Rev Med 48: 307-316, 1997.

15. Arner P and Kulyté A: MicroRNA regulatory networks in human adipose tissue and obesity. Nat Rev Endocrinol 11: 276-288, 2015.

16. Nedergaard J, Bengtsson T and Cannon B: Unexpected evidence for active brown adipose tissue in adult humans. Am J Physiol Endocrinol Metab 293: E444-E452, 2007.

17. Cypess AM, Lehman S, Williams G, Tal I, Rodman D, Goldfine AB, Kuo FC, Palmer EL, Tseng YH, Doria A, et al: Identification and importance of brown adipose tissue in adult humans. N Engl J Med 360: 1509-1517, 2009.

18. Saito M, Okamatsuogura Y, Matsushita M, Watanabe K, Yoneshiro T, Nio-Kobayashi J, Iwanaga T, Miyagawa M, Kameya T, Nakada K, et al: High incidence of metabolically active brown adipose tissue in healthy adult humans effects of cold exposure and adiposity. Diabetes 58: 1526-1531, 2009.

19. Virtanen KA, Lidell ME, Orava J, Heglind M, Westergren R, Niemi T, Taittonen M, Laine J, Savisto NJ, Enerbäck S and Nuutila P: Functional brown adipose tissue in healthy adults. N Engl J Med 360: 1518-1525, 2009

20. Orava J, Nuutila P, Lidell ME, Oikonen V, Noponen T, Viljanen T, Scheinin M, Taittonen M, Niemi T, Enerbäck S and Virtanen KA: Different metabolic responses of human brown adipose tissue to activation by cold and insulin. Cell Metab 14: 272-279, 2011.

21. Cannon B and Nedergaard J: Brown adipose tissue: Function and physiological significance. Physiol Rev 84: 277-359, 2004.

22. Heath V: Metabolism imaging studies suggest a role for brown adipose tissue in adult humans. Nat Rev Endocrinol 5: 411, 2009.

23. Young P, Arch JR and Ashwell M: Brown adipose tissue in the parametrial fat pad of the mouse. FEBS Lett 167: 10-14, 1984.

24. Cousin B, Cinti S, Morroni M, Raimbault S, Ricquier D, Pénicaud L and Casteilla L: Occurrence of brown adipocytes in rat white adipose tissue: Molecular and morphological characterization. J Cell Sci 103: 931-942, 1992.

25. Wu J, Boström P, Sparks LM, Ye L, Choi JH, Giang AH, Khandekar M, Virtanen KA, Nuutila P, Schaart G, et al: Beige adipocytes are a distinct type of thermogenic fat cell in mouse and human. Cell 150: 366-376, 2012.

26. Chen Y, Pan R and Pfeifer A: Regulation of brown and beige fat by microRNAs. Pharmacol Ther 170: 1-7, 2017.

27. Xue B, Rim JS, Hogan JC, Coulter AA, Koza RA and Kozak LP: Genetic variability affects the development of brown adipocytes in white fat but not in interscapular brown fat. J Lipid Res 48: 41-51, 2007.

28. Hoffmann LS, Larson CJ and Pfeifer A: cGMP and brown adipose tissue. Handb Exp Pharmacol 233: 283-299, 2016. 
29. Lenz LS, Marx J, Chamulitrat W, Kaiser I, Gröne HJ, Liebisch G, Schmitz G, Elsing C, Straub BK, Füllekrug J, et al: Adipocyte-specific inactivation of Acyl-CoA synthetase fatty acid transport protein 4 (Fatp4) in mice causes adipose hypertrophy and alterations in metabolism of complex lipids under high fat diet. J Biol Chem 286: 35578-35587, 2011.

30. Fukui Y, Masui S, Osada S, Umesono K and Motojima K: A new thiazolidinedione, NC-2100, which is a weak PPAR-gamma activator, exhibits potent antidiabetic effects and induces uncoupling protein 1 in white adipose tissue of KKAy obese mice. Diabetes 49: 759-767, 2000.

31. Wilson-Fritch L, Nicoloro S, Chouinard M, Lazar MA, Chui PC, Leszyk J, Straubhaar J, Czech MP and Corvera S: Mitochondrial remodeling in adipose tissue associated with obesity and treatment with rosiglitazone. J Clin Invest 114: 1281-1289, 2004.

32. Petrovic N, Walden TB, Shabalina IG, Timmons JA, Cannon B and Nedergaard J: Chronic peroxisome proliferator-activated receptor gamma (PPARgamma) activation of epididymally derived white adipocyte cultures reveals a population of thermogenically competent, UCP1-containing adipocytes molecularly distinct from classic brown adipocytes. J Biol Chem 285: 7153-7164, 2010.

33. Hondares E, Mora O, Yubero P, Rodriguez de la Concepción M, Iglesias R, Giralt M and Villarroya F: Thiazolidinediones and rexinoids induce peroxisome proliferator-activated receptor-coactivator (PGC)-1alpha gene transcription: An autoregulatory loop controls PGC-1alpha expression in adipocytes via peroxisome proliferator-activated receptor-gamma coactivation. Endocrinology 147: 2829-2838, 2006.

34. Zasloff M: Antimicrobial peptides of multicellular organisms. Nature 415: 389-395, 2002.

35. Lauressergues D, Couzigou JM, Clemente HS, Martinez Y, Dunand C, Bécard G and Combier JP: Primary transcripts of microRNAs encode regulatory peptides. Nature 520: 90-93, 2015.

36. Szafron LM, Balcerak A, Grzybowska EA, Pienkowska-Grela B, Felisiak-Golabek A, Podgorska A, Kulesza M, Nowak N, Pomorski P, Wysocki J, et al: The novel gene CRNDE encodes a nuclear peptide (CRNDEP) which is overexpressed in highly proliferating tissues. PLoS One 10: e0127475, 2015.

37. Matsumoto A, Pasut A, Matsumoto M, Yamashita R, Fung J, Monteleone E, Saghatelian A, Nakayama KI, Clohessy JG and Pandolfi PP: mTORC1 and muscle regeneration are regulated by the LINC00961-encoded SPAR polypeptide. Nature 541: 228-232, 2017.

38. Jaffe LA and Egbert JR: Regulation of mammalian oocyte meiosis by intercellular communication within the ovarian follicle. Annu Rev Physiol 79: 237-260, 2017.

39. Nguyen AD, Herzog H and Sainsbury A: Neuropeptide Y and peptide YY: Important regulators of energy metabolism. Curr Opin Endocrinol Diabetes Obes 18: 56-60, 2011.

40. Saido TC: Metabolism of amyloid $\beta$ peptide and pathogenesis of Alzheimer's disease. Proc Jpn Acad Ser B Phys Biol Sci 89: 321-339, 2013.

41. Celik O, Aydin S, Celik N and Yilmaz M: Peptides: Basic determinants of reproductive functions. Peptides 72: 34-43, 2015.

42. Cunha C, Panseri S and Gelain F: Engineering of a 3D nanostructured scaffold made of functionalized self-assembling peptides and encapsulated neural stem cells. Methods Mol Biol 1058: 171-182, 2013.

43. Long M, Zhou J, Li D, Zheng L, Xu Z and Zhou S: Long-term over-expression of neuropeptide $\mathrm{Y}$ in hypothalamic paraventricular nucleus contributes to adipose tissue insulin resistance partly via the Y5 receptor. PLoS One 10: e0126714, 2015.

44. Flier JS and Maratos-Flier E: Leptin's physiologic role: Does the emperor of energy balance have no clothes? Cell Metab 26: 24-26, 2017.

45. Rabbani G, Baig MH, Ahmad K and Choi I: Protein-protein interactions and their role in various diseases and their prediction techniques. Curr Protein Pept Sci 19: 948-957, 2018.

46. Henry S, Bercu NB, Bobo C, Cullin C, Molinari M and Lecomte $S$ : Interaction of $A \beta 1-42$ peptide or their variant with model membrane of different composition probed by infrared nanospectroscopy. Nanoscale 10: 936-940, 2018.

47. Brink HS, van der Lely AJ, Delhanty PJD, Huisman M and van der Linden J: Gestational diabetes mellitus and the ghrelin system. Diabetes Metab 45: 393-395, 2019.

48. Hoggard N, Haggarty P, Thomas L and Lea RG: Leptin expression in placental and fetal tissues: Does leptin have a functional role? Biochem Soc Trans 29: 57-63, 2001.
49. Picó C, Oliver P, Sánchez J and Palou A: Gastric leptin: A putative role in the short-term regulation of food intake. Br J Nutr 90: 735-741, 2003

50. Telli G, Tel BC, Yersal N, Korkusuz P and Gumusel B: Effect of intermedin/adrenomedullin ${ }_{2}$ on the pulmonary vascular bed in hypoxia-induced pulmonary hypertensive rats. Life Sci 192: 62-67, 2018.

51. Gao S, Ghoshal S, Zhang L, Stevens JR, McCommis KS, Finck BN, Lopaschuk GD and Butler AA: The peptide hormone adropin regulates signal transduction pathways controlling hepatic glucose metabolism in a mouse model of diet-induced obesity. J Biol Chem 294: 13366-13377, 2019.

52. Klok MD, Jakobsdottir S and Drent ML: The role of leptin and ghrelin in the regulation of food intake and body weight in humans: A review. Obes Rev 8: 21-34, 2007.

53. Montague CT, Farooqi IS, Whitehead JP, Soos MA, Rau H, Wareham NJ, Sewter CP, Digby JE, Mohammed SN, Hurst JA, et al: Congenital leptin deficiency is associated with severe early-onset obesity in humans. Nature 387: 903-908, 1997.

54. Jeon JY, Steadward RD, Wheeler GD, Bell G, McCargar L and Harber V: Intact sympathetic nervous system is required for leptin effects on resting metabolic rate in people with spinal cord injury. J Clin Endocrinol Metab 88: 402-407, 2003.

55. Farooqi IS, Keogh JM, Kamath S, Jones S, Gibson WT, Trussell R, Jebb SA, Lip GY and O'Rahilly S: Partial leptin deficiency and human adiposity. Nature 414: 34-35, 2001.

56. Sobhani I, Vissuzaine C, Buyse M, Kermorgant S, Laigneau JP, Henin D, Bado A and Lewin MJ: Leptin secretion and leptin receptor in human stomach. Gastroenterology 118: PA34, 2000.

57. Attele AS, Shi ZQ and Yuan CS: Leptin, gut, and food intake. Biochem Pharmacol 63: 1579-1583, 2002.

58. Sobhani I, Buyse M, Goïot H, Weber N, Laigneau JP, Henin D, Soul JC and Bado A: Vagal stimulation rapidly increases leptin secretion in human stomach. Gastroenterology 122: 259-263, 2002.

59. Dodd GT, Decherf S, Loh K, Simonds SE, Wiede F, Balland E, Merry TL, Münzberg H, Zhang ZY, Kahn BB, et al: Leptin and insulin act on POMC neurons to promote the browning of white fat. Cell 160: 88-104, 2015.

60. Friedman J: The long road to leptin. J Clin Invest 126: 4727-4734, 2016.

61. Cui H, López M and Rahmouni K: The cellular and molecular bases of leptin and ghrelin resistance in obesity. Nat Rev Endocrinol 13: 338-351, 2017.

62. Procaccini C, La Rocca C, Carbone F, De Rosa V, Galgani M and Matarese G: Leptin as immune mediator: Interaction between neuroendocrine and immune system. Dev Comp Immunol 66: 120-129, 2017.

63. Klein S, Horowitz JF, Landt M, Goodrick SJ, Mohamed-Ali V and Coppack SW: Leptin production during early starvation in lean and obese women. Am J Physiol Endocrinol Metab 278: E280-E284, 2000.

64. Chan JL, Kathleen H, Depaoli AM, Veldhuis JD and Mantzoros CS: The role of falling leptin levels in the neuroendocrine and metabolic adaptation to short-term starvation in healthy men. J Clin Invest 111: 1409-1421, 2003.

65. Duarte-Neves J, de Almeida LP and Cavadas C: Neuropeptide Y (NPY) as a therapeutic target for neurodegenerative diseases. Neurobiol Dis 95: 210-224, 2016.

66. Lee SJ, Verma S, Simonds SE, Kirigiti MA, Kievit P, Lindsley SR, Loche A, Smith MS, Cowley MA and Grove KL: Leptin stimulates neuropeptide $\mathrm{Y}$ and cocaine amphetamine-regulated transcript coexpressing neuronal activity in the dorsomedial hypothalamus in diet-induced obese mice. J Neurosci 33: 15306-15317, 2013.

67. Loh K, Herzog H and Shi YC: Regulation of energy homeostasis by the NPY system. Trends Endocrinol Metab 26: 125-135, 2015.

68. Shi YC, Lau J, Lin Z, Zhang H, Zhai L, Sperk G, Heilbronn R, Mietzsch M, Weger S, Huang XF, et al: Arcuate NPY controls sympathetic output and BAT function via a relay of tyrosine hydroxylase neurons in the PVN. Cell Metab 17: 236-248, 2013.

69. Kuo LE, Kitlinska JB, Tilan JU, Li L, Baker SB, Johnson MD, Lee EW, Burnett MS, Fricke ST, Kvetnansky R, et al: Neuropeptide $\mathrm{Y}$ acts directly in the periphery on fat tissue and mediates stress-induced obesity and metabolic syndrome. Nat Med 13: 803-811, 2007.

70. Pandey SC: Anxiety and alcohol abuse disorders: A common role for CREB and its target, the neuropeptide Y gene. Trends Pharmacol Sci 24: 456-460, 2003.

71. Meier JJ: GLP-1 receptor agonists for individualized treatment of type 2 diabetes mellitus. Nat Rev Endocrinol 8: 728-742, 2012. 
72. Vogel H, Wolf S, Rabasa C, Rodriguez-Pacheco F, Babaei CS, Stöber F, Goldschmidt J, DiMarchi RD, Finan B, Tschöp MH, et al: GLP-1 and estrogen conjugate acts in the supramammillary nucleus to reduce food-reward and body weight. Neuropharmacology 110: 396-406, 2016.

73. Baggio LL, Huang Q, Brown TJ and Drucker DJ: Oxyntomodulin and glucagon-like peptide-1 differentially regulate murine food intake and energy expenditure. Gastroenterology 127: 546-558, 2004.

74. Turton MD, O'Shea D, Gunn I, Beak SA, Edwards CM, Meeran K, Choi SJ, Taylor GM, Heath MM, Lambert PD, et al: A role for glucagon-like peptide-1 in the central regulation of feeding. Nature 379: 69-72, 1996.

75. Perez-Tilve D, Nogueiras R, Mallo F, Benoit SC and Tschoep M: Gut hormones ghrelin, PYY, and GLP-1 in the regulation of energy balance [corrected] and metabolism. Endocrine 29: 61-71, 2006.

76. ElBekay R,Coín-AragüezL,Fernández-GarcíaD,Oliva-Olivera W, Bernal-López R, Clemente-Postigo M, Delgado-Lista J, Diaz-Ruiz A, Guzman-Ruiz R, Vázquez-Martínez R, et al: Effects of glucagon-like peptide-1 on the differentiation and metabolism of human adipocytes. Br J Pharmacol 173: 1820-1834, 2016.

77. Xu F, Lin B, Zheng X, Chen Z, Cao H, Xu H, Liang H and Weng J: GLP-1 receptor agonist promotes brown remodelling in mouse white adipose tissue through SIRT1. Diabetologia 59: 1059-1069, 2016.

78. Kojima M, Hosoda H, Date Y, Nakazato M, Matsuo H and Kangawa $\mathrm{K}$ : Ghrelin is a growth-hormone-releasing acylated peptide from stomach. Nature 402: 656-660, 1999.

79. Garin MC, Burns CM, Kaul S and Cappola AR: Clinical review: The human experience with ghrelin administration. J Clin Endocrinol Metab 98: 1826-1837, 2013.

80. Yakabi K, Kawashima J and Kato S: Ghrelin and gastric acid secretion. World J Gastroenterol 14: 6334-6338, 2008.

81. Tritos NA and Kokkotou EG: The physiology and potential clinical applications of ghrelin, a novel peptide hormone. Mayo Clin Proc 81: 653-660, 2006.

82. Tschöp M, Smiley DL and Heiman ML: Ghrelin induces adiposity in rodents. Nature 407: 908-913, 2000.

83. Shaw AM, Irani BG, Moore MC, Haskell-Luevano C and Millard WJ: Ghrelin-induced food intake and growth hormone secretion are altered in melanocortin 3 and 4 receptor knockout mice. Peptides 26: 1720-1727, 2005

84. Kirchner H, Tong J, Tschöp MH and Pfluger PT: Ghrelin and PYY in the regulation of energy balance and metabolism: Lessons from mouse mutants. Am J Physiol Endocrinol Metab 298: E909-E919, 2010.

85. Mihalache L, Gherasim A, Niță O, Ungureanu MC, Pădureanu SS, Gavril RS and Arhire LI: Effects of ghrelin in energy balance and body weight homeostasis. Hormones (Athens) 15: 186-196, 2016.

86. Kitahara A, Takahashi K, Moriya R, Onuma H, Handa K, Sumitani Y, Tanaka T, Katsuta H, Nishida S, Sakurai T, et al: Ghrelin augments the expressions and secretions of proinflammatory adipokines, VEGF120 and MCP-1, in differentiated 3T3-L1 adipocytes. J Cell Physiol 230: 199-209, 2015.

87. Cummings DE, Purnell JQ, Frayo RS, Schmidova K, Wisse BE and Weigle DS: A preprandial rise in plasma ghrelin levels suggests a role in meal initiation in humans. Diabetes 50: $1714-1719,2001$.

88. van der Lely AJ, Tschöp M, Heiman ML and Ghigo E: Biological, physiological, pathophysiological, and pharmacological aspects of ghrelin. Endocr Rev 25: 426-457, 2004.

89. Bell D and McDermott BJ: Intermedin (adrenomedullin-2): A novel counter-regulatory peptide in the cardiovascular and renal systems. Br J Pharmacol 153 (Suppl 1): S247-S262, 2008.

90. Zhang SY, Lv Y, Zhang H, Gao S, Wang T, Feng J, Wang Y, Liu G, Xu MJ, Wang X and Jiang C: Adrenomedullin 2 improves early obesity-induced adipose insulin resistance by inhibiting the class II MHC in adipocytes. Diabetes 65: 2342-2355, 2016.

91. Boström P, Wu J, Jedrychowski MP, Korde A, Ye L, Lo JC, Rasbach KA, Boström EA, Choi JH, Long JZ, et al: A PGC1- $\alpha$-dependent myokine that drives brown-fat-like development of white fat and thermogenesis. Nature 481: 463-468, 2012.

92. Metwally M, Bayoumi A, Romero-Gomez M, Thabet K, John M, Adams LA, Huo X, Aller R, García-Monzón C, Teresa Arias-Loste $\mathrm{M}$, et al: A polymorphism in the Irisin-encoding gene (FNDC5) associates with hepatic steatosis by differential miRNA binding to the 3'UTR. J Hepatol 70: 494-500, 2019.
93. Moreno-Navarrete JM, Ortega F, Serrano M, Guerra E, Pardo G, Tinahones F, Ricart W and Fernández-Real JM Irisin is expressed and produced by human muscle and adipose tissue in association with obesity and insulin resistance. J Clin Endocrinol Metab 98: E769-E778, 2013.

94. Pérez-Sotelo D, Roca-Rivada A, Baamonde I, Baltar J, Castro AI, Domínguez E, Collado M, Casanueva FF and Pardo M: Lack of adipocyte-Fndc5/Irisin expression and secretion reduces thermogenesis and enhances adipogenesis. Sci Rep 7: 16289, 2017.

95. Lee P, Linderman JD, Smith S, Brychta RJ, Wang J, Idelson C, Perron RM, Werner CD, Phan GQ, Kammula US, et al: Irisin and FGF21 are cold-induced endocrine activators of brown fat function in humans. Cell Metab 19: 302-309, 2014.

96. Ghoshal S, Stevens JR, Billon C, Girardet C, Sitaula S, Leon AS, Rao DC, Skinner JS, Rankinen T, Bouchard C, et al: Adropin: An endocrine link between the biological clock and cholesterol homeostasis. Mol Metab 8: 51-64, 2018.

97. Ganesh Kumar K, Zhang J, Gao S, Rossi J, McGuinness OP, Halem HH, Culler MD, Mynatt RL and Butler AA: Adropin deficiency is associated with increased adiposity and insulin resistance. Obesity (Silver Spring) 20: 1394-1402, 2012.

98. Chen S, Zeng K, Liu QC, Guo Z, Zhang S, Chen XR, Lin JH, Wen JP, Zhao CF, Lin XH and Gao F: Adropin deficiency worsens HFD-induced metabolic defects. Cell Death Dis 8: e3008, 2017.

99. Jasaszwili M, Wojciechowicz T, Billert M, Strowski MZ, Nowak KW and Skrzypski M: Effects of adropin on proliferation and differentiation of 3T3-L1 cells and rat primary preadipocytes. Mol Cell Endocrinol 496: 110532, 2019.

100. Aydin S: Three new players in energy regulation: Preptin, adropin and irisin. Peptides 56: 94-110, 2014.

101. Mierzwicka A and Bolanowski M: New peptides players in metabolic disorders. Postepy Hig Med Dosw (Online) 70: 881-886, 2016

102. El-Eshmawy M and Abdel Aal I: Relationships between preptin and osteocalcin in obese, overweight, and normal weight adults. Appl Physiol Nutr Metab 40: 218-222, 2015

103. Chen X, Zaro JL and Shen WC: Fusion protein linkers: Property, design and functionality. Adv Drug Deliv Rev 65: 1357-1369, 2013.

104. Plamboeck A, Holst JJ, Carr RD and Deacon CF: Neutral endopeptidase 24.11 and dipeptidyl peptidase IV are both involved in regulating the metabolic stability of glucagon-like peptide-1 in vivo. Adv Exp Med Biol 524: 303-312, 2003.

105. Tomas E, Wood JA, Stanojevic V and Habener JF: GLP-1-derived nonapeptide GLP-1(28-36)amide inhibits weight gain and attenuates diabetes and hepatic steatosis in diet-induced obese mice. Regul Pept 169: 43-48, 2011.

106. Tomas E, Wood JA, Stanojevic V and Habener JF: Glucagon-like peptide-1(9-36)amide metabolite inhibits weight gain and attenuates diabetes and hepatic steatosis in diet-induced obese mice. Diabetes Obes Metab 13: 26-33, 2011

107. Tomas E, Stanojevic V, McManus K, Khatri A, Everill P, Bachovchin WW and Habener JF: GLP-1(32-36)amide pentapeptide increases basal energy expenditure and inhibits weight gain in obese mice. Diabetes 64: 2409-2419, 2015

108. Jankovic J: Parkinson disease: Exenatide-a drug for diabetes and Parkinson disease? Nat Rev Neurol 13: 643-644, 2017.

109. Bondeson DP and Crews CM: Targeted protein degradation by small molecules. Annu Rev Pharmacol Toxicol 57: 107-123, 2017.

110. Demirel HC, Dogan T and Tuncbag N: A structural perspective on the modulation of protein-protein interactions with small molecules. Curr Top Med Chem 18: 700-713, 2018.

111. Svensson KJ, Long JZ, Jedrychowski MP, Cohen P, Lo JC, Serag S, Kir S, Shinoda K, Tartaglia JA, Rao RR, et al: A secreted Slit 2 fragment regulates adipose tissue thermogenesis and metabolic function. Cell Metab 23: 454-466, 2016.

112. Phuong TTT, Walker AE, Henson GD, Machin DR, Li DY, Donato AJ and Lesniewski LA: Deletion of Robo4 prevents high-fat diet-induced adipose artery and systemic metabolic dysfunction. Microcirculation 26: e12540, 2019.

113. Romere C, Duerrschmid C, Bournat J, Constable P, Jain M, Xia F, Saha PK, Del Solar M, Zhu B, York B, et al: Asprosin, a fasting-induced glucogenic protein hormone. Cell 165: 566-579, 2016.

114. Ricci-Cabello I, Herrera MO and Artacho R: Possible role of milk-derived bioactive peptides in the treatment and prevention of metabolic syndrome. Nutr Rev 70: 241-255, 2012.

115. Capriotti AL, Cavaliere C, Piovesana S, Samperi R and Laganà $\mathrm{A}$ : Recent trends in the analysis of bioactive peptides in milk and dairy products. Anal Bioanal Chem 408: 2677-2685, 2016. 
116. Sawada Y, Sakamoto Y, Toh M, Ohara N, Hatanaka Y, Naka A Kishimoto $\mathrm{Y}$, Kondo K and Iida K: Milk-derived peptide Val-Pro-Pro (VPP) inhibits obesity-induced adipose inflammation via an angiotensin-converting enzyme (ACE) dependent cascade. Mol Nutr Food Res 59: 2502-2510, 2016.

117. Xu SP, Mao XY, Cheng X and Chen B: Ameliorating effects of casein glycomacropeptide on obesity induced by high-fat diet in male sprague-dawley rats. Food Chem Toxicol 56: 1-7, 2013.

118. Cui X, Li Y, Yang L, You L, Wang X, Shi C, Ji C and Guo X: Peptidome analysis of human milk from women delivering macrosomic fetuses reveals multiple means of protection for infants. Oncotarget 7: 63514-63525, 2016.

119. Azkargorta M, Escobes I, Iloro I and Elortza F: Mass spectrometric identification of endogenous peptides. Methods Mol Biol 1719: 59-70, 2018.

120. Goldberg AL: Protein degradation and protection against misfolded or damaged proteins. Nature 426: 895-899, 2003.

121. Lázaro S, Gamarra D and Val M: Proteolytic enzymes involved in MHC class I antigen processing: A guerrilla army that partners with the proteasome. Mol Immunol 68: 72-76, 2015.

122. Fricker LD: Analysis of mouse brain peptides using mass spectrometry-based peptidomics: Implications for novel functions ranging from non-classical neuropeptides to microproteins. Mol Biosyst 6: 1355-1365, 2010.

123. Castro LM, Berti DA, Russo LC, Coelho V, Gozzo FC, Oliveira V and Ferro ES: Similar intracellular peptide profile of TAP1/ $\beta 2$ microglobulin double-knockout mice and C57BL/6 wild-type mice as revealed by peptidomic analysis. AAPS J 12: 608-616, 2010.

124. Gelman JS, Juan S, Castro LM, Ferro ES and Fricker LD Peptidomic analysis of human cell lines. J Proteome Res 10 1583-1592, 2011

125. Cunha FM, Berti DA, Ferreira ZS, Klitzke CF, Markus RP and Ferro ES: Intracellular peptides as natural regulators of cell signaling. J Biol Chem 283: 24448-24459, 2008.

126. Haynes CM, Yang Y, Blais SP, Neubert TA and Ron D: The matrix peptide exporter HAF-1 signals a mitochondrial UPR by activating the transcription factor ZC376.7 in C. elegans. Mol Cell 37: 529-540, 2010

127. Berti DA, Russo LC, Castro LM, Cruz L, Gozzo FC, Heimann JC Lima FB, Oliveira AC, Andreotti S, Prada PO, et al: Identification of intracellular peptides in rat adipose tissue: Insights into insulin resistance. Proteomics 12: 2668-2681, 2012.

128. Liu Y, Luo B, Shi R, Wang J, Liu Z, Liu W, Wang S and Zhang Z: Nonerythropoietic erythropoietin-derived peptide suppresses adipogenesis, inflammation, obesity and insulin resistance. Sci Rep 5: 15134, 2015.
129. Sodhi K, Maxwell K, Yan Y, Liu J, Chaudhry MA, Getty M, Xie Z, Abraham NG and Shapiro JI: pNaKtide inhibits $\mathrm{Na} / \mathrm{K}$-ATPase reactive oxygen species amplification and attenuates adipogenesis. Sci Adv 1: e1500781, 2015.

130. Ogden CL, Carroll MD, Kit BK and Flegal KM: Prevalence of childhood and adult obesity in the United States, 2011-2012. JAMA 311: 806-814, 2014.

131. Ferro ES, Rioli V, Castro LM and Fricker LD: Intracellular peptides: From discovery to function. EuPA Open Proteom 3: $143-151,2014$

132. Forner F, Kumar C, Luber CA, Fromme T, Klingenspor M and Mann M: Proteome differences between brown and white fat mitochondria reveal specialized metabolic functions. Cell Metab 10: 324-335, 2009

133. Iepsen EW, Torekov SS and Holst JJ: Therapies for inter-relating diabetes and obesity-GLP-1 and obesity. Expert Opin Pharmacother 15: 2487-2500, 2014.

134. Desilets AR, Dhakal-Karki S and Dunican KC: Role of metformin for weight management in patients without type 2 diabetes. Ann Pharmacother 42: 817-826, 2008.

135. Gao Y, Wang X, Huang F, Cui X, Li Y, Wang X, Cao Y, Xu P, Xie K, Tang R, et al: Identification and characterization of metformin on peptidomic profiling in human visceral adipocytes. J Cell Biochem 119: 1866-1878, 2018.

136. Lee C, Zeng J, Drew BG, Sallam T, Martin-Montalvo A, Wan J, Kim SJ, Mehta H, Hevener AL, de Cabo R and Cohen P: The mitochondrial-derived peptide MOTS-c promotes metabolic homeostasis and reduces obesity and insulin resistance. Cell Metab 21: 443-454, 2015.

137. Bessesen DH and Van Gaal LF: Progress and challenges in anti-obesity pharmacotherapy. Lancet Diabetes Endocrinol 6: 237-248, 2018

138. Iwasaki Y, Sendo M, Dezaki K, Hira T, Sato T, Nakata M, Goswami C, Aoki R, Arai T, Kumari P, et al: GLP-1 release and vagal afferent activation mediate the beneficial metabolic and chronotherapeutic effects of D-allulose. Nat Commun 9: 113, 2018.

139. Jones B, Bloom SR, Buenaventura T, Tomas A and Rutter GA: Control of insulin secretion by GLP-1. Peptides 100: 75-84, 2018.

140. Carter A, Hendrikse J, Lee N, Yücel M, Verdejo-Garcia A, Andrews ZB and Hall W: The neurobiology of 'food addiction' and its implications for obesity treatment and policy. Annu Rev Nutr 36: 105-128, 2016.

141. Rebello CJ and Greenway FL: Obesity medications in development. Expert Opin Investig Drugs 29: 63-71, 2020. 